\title{
PERTUMBUHAN PERMUKIMAN DI KECAMATAN BULELENG
}

\author{
Samuelina Situmorang ${ }^{1}$, I Gede Astra Wesnawa ${ }^{2 *}$
}

Pendidikan Geografi, Universitas Pendidikan Ganesha, Indonesia

\section{A R T I C L EI N F O}

Article history:

Received 19 Desember 2018

Received in revised form

17Februari 2018

Accepted 12 Maret 2018

Available online 31 Maret

2018

Kata Kunci:

Karakteristik

Pertumbuhan

Permukiman

Keywords:

Characteristic

Development

Settlement

\begin{abstract}
A B S T R A K
Penelitian dilaksanakan di Kecamatan Buleleng, yang bertujuan untuk: (1) menganalisis tingkat pertumbuhan permukiman, (2) menganalisis arah pertumbuhan permukiman, dan (3) menganalisis karakteristik permukiman. Pengumpulan data meliputi teknik observasi, teknik pencatatan dokumen, dan kepustakaan. Hasil penelitian ini menunjukkan bahwa: (1) tingkat pertumbuhan permukiman di Kecamatan Buleleng mengalami peningkatan dari tahun 2000 - 2016 sebesar 42,74 \%. (2) arah pertumbuhan permukiman di Kecamatan Buleleng mengarah ke arah timur dan barat Kecamatan Buleleng, (3) Karakteristik pertumbuhan permukiman di Kecamatan Buleleng bukan hanya permukiman pribadi, permukiman umum juga mengalami pertumbuhan. Kelurahan paling banyak pertumbuhan permukiman pribadi adalah Banyuasri dan Banyuning, paling sedikit di Kampung Singaraja dan Paket Agung, sedangkan pertumbuhan permukimannya paling banyak permukiman umum adalah Kelurahan Kalibukbuk dan paling sedikit di Banyuasri.
\end{abstract}

\section{A B S T R A C T}

The study was conducted in Buleleng districts. The purposes of this study were: (1) to analyze the level of settlement development, (2) to analyze the direction of settlement development, and (3) to analyze the characteristics of settlement itself. The population of this study contains of 29 sub-districts. The data collection for this study covers the observation technique of the target location, the technique of documentation records and its literature. The result of this study shows that: (1) The level of settlement development in Buleleng districts was increased 42,74\% from year 2000-2016. (2) Direction of the settlement development in Buleleng districts leads to east and west of Buleleng. It shows the large amount directions of settlement development was in Banyuning sub-districts. Beratan and Banyuasri are subdistricts which located in suburb between the city and the village in Buleleng district. (3) The characteristics of settlement development in Buleleng district not only just for the private settlement, however public settlement also developed. Banyuasri and Banyuning are sub-districts in which have the big development of privat settlement, in the other side Kampung Singaraja and Paket Agung are subdistrict which have less development in Buleleng. Whereas Kalibukbuk is the sub-district in which has big development of the public settlement, and Banyuasri is the sub district which has less development in public settlement.

\footnotetext{
* Corresponding author.

E-mail addresses:igedeastra62@gmail.com(Penulis Kedua)
} 


\section{Pendahuluan}

Indonesia merupakan negara yang memiliki jumlah penduduk yang terpadat nomor empat di dunia setelah China, India, dan Amerika Serikat. Kepadatan penduduk merupakan kondisi dimana jumlah penduduknya tidak sesuai dengan kapasitas tanah yang ditempati (Weran, 2017). Kepadatan penduduk yang terjadi di Negara Indonesia, disebabkan karena Negara Indonesia belum mampu menekan laju pertumbuhan penduduk. Pertumbuhan penduduk dipengaruhi oleh tiga faktor yaitu kelahiran, kematian, dan migrasi. Dari ketiga faktor tersebut, fertilitas yang memegang peran penting dalam pertumbuhan penduduk (Susilo, 2015). Seiring dengan semakin bertambahnya jumlah penduduk yang ada di Indonesia, tidak terlepas dari semakin banyaknya permukiman-permukiman yang dibutuhkan penduduk untuk bertempat tinggal. Pertumbuhan penduduk mendorong peningkatan kebutuhan lahan, baik lahan untuk tempat tinggal, sarana penunjang kehidupan, industri, tempat pertanian, dan sebagainya (Ismail, Sriartha, \& Sutarjo, 2016).

Pembangunan permukiman merupakan sebagai salah satu kebutuhan utama bagi warga, baik yang bertempat tinggal di daerah perkotaan maupun perdesaan, telah menjadi masalah pokok yang sangat penting untuk saat ini maupun masa yang akan datang. Sebagaimana Perumahan dan permukiman merupakan salah satu kebutuhan pokok manusia. Berdasarkan Undang Undang Dasar 1945 Pasal 28 Tentang Rumah, n.d. mengatakan bahwa rumah adalah salah satu hak dasar rakyat dan oleh karena itu setiap Warga Negara berhak untuk bertempat tinggal dan mendapat lingkungan hidup yang baik dan sehat.

Permukiman penduduk yang mengalami pertumbuhan dan mengalami perkembangan, sudah menjadi permasalahan dalam kependudukan Indonesia. Disusul lagi dengan semakin banyaknya pembangunan permukiman yang tidak memenuhi syarat untuk dijadikaan sebagai tempat tinggal atau bermukimnya penduduk. Permukiman penduduk masih banyak dibangun pada daerah-daerah rawan bencana, seperti rawan banjir, hal ini dikarenakan semakin banyaknya dibutuhkan ruang untuk bermukimnya penduduk.

Pulau Bali merupakan salah satu Provinsi di Indonesia yang memiliki peningkatan laju pertumbuhan penduduk. Peningkatan laju pertumbuhan penduduk ditunjukkan pada data tahun 2000 jumlah penduduk Bali 3.146.999 dan pada tahun 2010 jumlah penduduknya 3.890.757 (Badan Pusat Statistik Provinsi Bali, 2010). Provinsi Bali, memiliki sembilan kabupaten, salah satunya Kabupaten Buleleng. Kabupaten Buleleng merupakan kabupaten yang terdapat di Pulau Bali, yang wilayahnya paling luas di antara Kabupaten lainnya di Provinsi Bali. Luas wilayah Kabupaten Buleleng adalah 1.364,73 km².

Kabupaten Buleleng terdiri dari sembilan kecamatan, Kecamatan Gerogak, Seririt, Busung biu, Banjar, Sukasada, sawan, Kubutanbahan, Tejakula, dan Kecamatan Buleleng. Diantara sembilan kecamatan yang ada di Kabupaten Buleleng tersebut, berdasarkan data Sensus (Badan Pusat Statistik Kabupaten Buleleng, 2010), Kecamatan Buleleng merupakan kecamatan yang terbanyak nomor satu penduduknya di Kabupaten Buleleng. 
Jumlah penduduk di Kecamatan Buleleng berdasarkan data sensus penduduk dari tahun 1961 sampai 2010 mengalami pertumbuhan penduduk. Pertumbuhan penduduk yang terjadi di Kecamatan Buleleng tidak hanya disebabkan karena terjadinya kelahiran pada masyarakat lokal, melainkan disebabakan karena adanya perpindahan penduduk dari kecamatan lain, maupun dari luar Provinsi Bali. Permukiman mengalami pertumbuhan mengiringi laju pertumbuhan penduduk, Buleleng yang memiliki pertumbuhan penduduk relatif tinggi yaitu 1,89\% dan terbentuknya keluarga batih mengakibatkan meningkatkan kebutuhan lahan untuk permukiman mikro (Wesnawa, 2015). Maka penelitian ini dilakukan untuk mengetahui pertumbuhan permukiman yang terjadi di Kecamatan Buleleng dari tahun 2000 sampai pada tahun 2016.

Berdasarkan latar belakang di atas, maka dalam penelitian ini dapat dirumuskan beberapa masalah sebagai berikut: (1) bagaimana tingkat pertumbuhan permukiman yang terjadi di Kecamatan Buleleng, (2) bagaimana arah pertumbuhan permukiman di Kecamatan Buleleng, (3) bagaimana karakteristik pertumbuhan permukiman di Kecamatan Buleleng ?. Adapun tujuan dari penelitian ini untuk : (1) menganalisis tingkat pertumbuhan permukiman di Kecamatan Buleleng, (2) menganalisis arah pertumbuhan permukiman di Kecamatan Buleleng, (3) menganalisis karakteristik pertumbuhan permukiman di Kecamatan Buleleng.

Berdasarkan rumusan masalah tersebut, maka adapun landasan teori yang digunakan untuk menjawab masalah dalam penelitian ini adalah sebagai berikut:Pengertian permukiman menurut Hudson dan Hammond, (dalam Wesnawa, 2015), Permukiman adalah tempat tinggal atau tempat kediaman secara umum disebut permukiman dan secara khusus disebut sebagai bagunan rumah. Pengertian permukiman menurut Hadi Sabari Yunus (dalam Wesnawa, 2015), permukiman dapat diartikan sebagai bentukan baik buatan manusia ataupun alami dengan segala kelengkapan yang digunakan manusia sebagai individu maupun kelompok untuk bertempat tinggal baik sementara maupun menetap dalam menyelenggarakan kehidupanya. Pengertian permukiman menurut Barlow (dalam Wesnawa, 2015), permukiman adalah semua tipe tempat tinggal manusia baik suatu gubug atau pondok tunggal beratap dadaunan atau rumah-rumah di perladangan hingga kota yang sangat besar ribuan bangunan atau ribuan rumah tempat tinggal.

Skala dalam permukiman ialah, skala makro, skala meso, dan skala mikro. skala permukiman makro, ekspresi keruangan dari pada permukimannya berwujud sebagai kenampakan kota-kota secara individual ataupun gabungan dari beberapa permukiman kota yang telah membentuk suatu built-up areas yang sangat besar (Wesnawa, 2015). Skala permukiman meso, meneliti bagian tertentu dari kota-kota secara individual yang betul-betul digunakan untuk tempat tinggal penduduk. Dalam bahasa sehari-hari dikenal kampong, blok, dan komplek perumahan (Wesnawa, 2015). Dalam skala permukiman mikro, perlu dipahami istilah neighbourhood unit atau satuan lingkungan tempat kediaman. Rumah-rumah dan sekitarnya merupakan ajang pergaulan penduduk. Dalam lingkungan tempat kediaman ini terdapat lima element yang masing-masing element saling mempengaruhi, house building, housing facilities,sanitation, envirionment condition, aesthetic and architecultural aspects. 
Berdasarkan pertumbuhannya, permukiman dapat dibedakan menurut permukiman muda, dewasa, dan tua. Berdasarkan karakteristik pertumbuhannya, cepat atau lambatnya pertumbuhan permukiman dibedakan atas invasi (instasi) dan infiltrasi (sedikit demi sedikit). Pertumbuhan permukiman terjadi sebelum permukiman mengalami perkembangan, karena pertumbuhan merupakan pengembangan, persebaran atau peningkatan dari aktivitas yang dilakukan oleh individu maupun oleh komunitas masyarakat. Pada penelitian ini yang dimaksud pertumbuhan permukiman baru, ialah adanya pertambahan jumlah dari pada permukiman yang ada, Pertumbuhan permukiman baru yang terjadi untuk memenuhi kebutuhan dari penduduk yang juga mengalami peningkatan, maka pertumbuhan atau peningkatan pertumbuhan permukiman yang terjadi dalam suatu wilayah memiliki perbedaan masing-masing dalam proses pertumbuhannya (Wesnawa, 2015).

Tingkat pertumbuhan permukiman yang terjadi di Desa maupun Kota mengalami peningkatan pertumbuhan permukiman untuk memenuhi kebutuhan hidup masyarakat atau penduduknya. Pembangunan permukiman yang tidak merata disejumlah daerah menyebabkan adanya perbedaan tingkat pertumbuhan permukiman (Masitoh, 2003). Pertumbuhan permukiman mengalami pertumbuhan cenderung kearah pinggiran kota (peri urban). Wilayah pinggiran kota (peri urban), merupakan peralihan dari wilayah kota dan wilayah desa yang memiliki atribut yang berbeda (Hariyanto, 2007).

Semakin besar interaksi kota dengan wilayah pinggiran kota (peri urban), maka akan semakin besar pula perkembangan didaerah pinggiran kota. Pola dan arah permukiman yang terbentuk di suatu wilayah peri urban juga memperlihatkan wilayah mana yang memberikan pengaruh besar terhadap wilayah peri urban tersebut (Jati \& Christanto, 2012). Berdasarkan pendapat tersebut arah pertumbuhan permukiman mengarah pada pinggiran kota, karena pemenuhan ruang permukiman yang terbatas. Namun tidak menutup kemungkinan arah pertumbuhan permukiman tidak pada pinggiran kota saja.

Karakteristik pertumbuhan permukiman yang terjadi di kota, pinggiran kota dan desa memiliki karakteristik permukiman yang berbeda-beda. di kota cenderung permukiman elit, di pinggiran kota permukiman karakteristik pertumbuhannya yaitu permukiman umum atau perumahan karena adanya pengaruh kota, penduduknya ekonomi sedang dan rendah, di desa karakteristik permukimanya permukiman pribadi penduduknya sebagian besar bekerja sebagai petani (Masykur, 2006).

\section{Metode}

Penelitian ini menggunakan pendekatan keruangan, yang menekankan pada beberapa aspek keruangan dan menggunakan rancangan penelitian deskriptif kuantitatif. Penelitian ini dilaksanakan di Kecamatan Buleleng, dengan objek penelitianya adalah pertumbuhan permukiman baru penduduk di Kecamatan Buleleng. Sedangkan subjek pada penelitian ini adalah data citra satelit. Penelitian ini merupakan penelitian populasi. Data dikumpulkan dengan teknik observasi, pencatatan dokumen, dan studi kepustakaan dan dianalisis dengan menggunakan teknik deskriptif kuantitatif. 


\section{Hasil dan Pembahasan}

\subsection{Tingkat pertumbuhan permukiman yang terjadi di Kecamatan Buleleng}

Tingkat pertumbuhan permukiman yang terjadi di Kecamatan BulelengPermukiman penduduk di Kecamatan Buleleng mengalami pertumbuhan, dari tahun 2000 - 2016, dapat dilihat pada Gambar 1. dan Gambar 2. berikut ini:

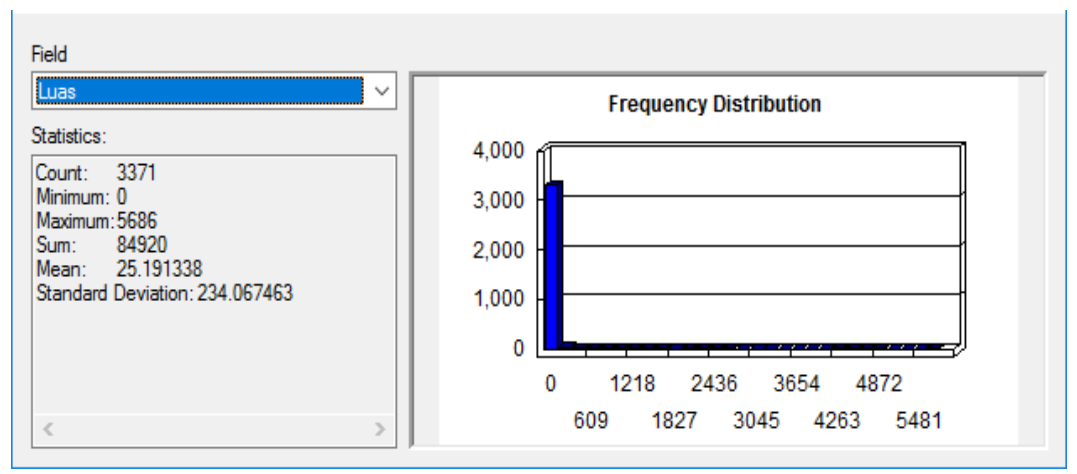

Gambar 1. Frequensi distribusi (luas permukiman) tahun 2000. Sumber : Data sekunder (citra landsat), diolah oleh peneliti 2017

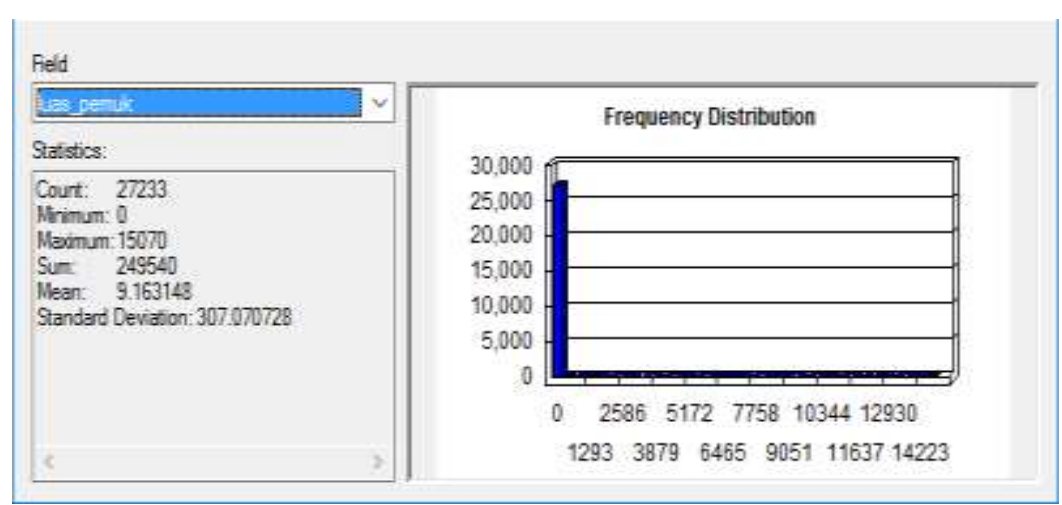

Gambar 2. frekuensi distribusi (luas permukiman) tahun 2016. Sumber: Data sekunder (citra landsat), diolah oleh peneliti 2017.

Pada tahun 2000 luas permukiman penduduk secara keseluruhan di Kecamatan Buleleng adalah seluas 84920 are ( 10,42\%). Gambar 4.4 Pada tahun 2016 luas permukiman secara keseluruhan adalah seluas 249540 are $(53,16 \%)$. Dari data luas permukiman yang sudah didapatkan pada tahun 2000 dan 2016, maka permukiman penduduk mengalami perluasan dari tahun 2000 - 2016 adalah seluas 164620 are (42,74\%). Tahun 2000 dan 2016 dari data yang sudah didapatkan maka permukiman penduduk mengalami pertumbuhan permukiman penduduk.

\subsection{Arah pertumbuhan permukiman di Kecamatan Buleleng}

Pertumbuhan permukiman di Kecamatan Buleleng dapat diketahui melalui pengolahan data citra landsat pada tahu 2000-2016. Arah pertumbuhan permukiman 
diKecamatan Bulelen, dapat diketahui arah pertumbuhannya, unruk lebih jelasnya dapat dilihat pada tabel 3. berikut:

Tabel 3. Luas Permukiman Penduduk Per Desa Di Kecamatan Buleleng Tahun 2000-2016

\begin{tabular}{|c|c|c|c|}
\hline \multirow[t]{2}{*}{ No } & \multirow[t]{2}{*}{ Kelurahan/ Desa } & \multicolumn{2}{|c|}{ Tahun } \\
\hline & & 2000 & 2016 \\
\hline 1 & Kalibukbuk & 1,24 & 2,72 \\
\hline 2 & Anturan & 1,27 & 1,86 \\
\hline 3 & Tukad Mungga & 0,71 & 0,91 \\
\hline 4 & Pemaron & 0,91 & 0,99 \\
\hline 5 & Bakti Seraga & 0,37 & 2,80 \\
\hline 6 & Banyuasri & 0,26 & 5,12 \\
\hline 7 & Banjar Tegal & 1,07 & 4,22 \\
\hline 8 & Paket Agung & 0,37 & 0,54 \\
\hline 9 & Beratan & 0,30 & 5,01 \\
\hline 10 & Liligundi & 0,31 & 0,61 \\
\hline 11 & Kampong Singaraja & 0,21 & 0,42 \\
\hline 12 & Kendara & 0,37 & 0,58 \\
\hline 13 & Astina & 0,57 & 3,47 \\
\hline 14 & Banjar Jawa & 0,92 & 3,27 \\
\hline 15 & Banjar Bali & 0,19 & 3,21 \\
\hline 16 & Kampong Kanjana & 0,22 & 3,21 \\
\hline 17 & Kaliuntu & 1,21 & 3,78 \\
\hline 18 & Kampong Anyar & 0,57 & 3,23 \\
\hline 19 & Kampong Bugis & 0,34 & 3,21 \\
\hline 20 & Kampong Baru & 0,97 & 3,27 \\
\hline 21 & Banyuning & 0,46 & 5,01 \\
\hline 22 & Penarukan & 1,95 & 1,98 \\
\hline 23 & Jinengdalem & 0,63 & 0,92 \\
\hline 24 & Penglatan & 0,47 & 0,55 \\
\hline 25 & Petandakan & 0,73 & 0,91 \\
\hline 26 & Sari Mekar & 0,62 & 0,90 \\
\hline 27 & Nagasepah & 0,22 & 0,54 \\
\hline 28 & Alas Angker & 0,26 & 0,62 \\
\hline 29 & Poh Bergong & 0,48 & 0,98 \\
\hline
\end{tabular}

Sumber : data sekunder (citra landsat 7, tahun 2000 ), diolah oleh peneliti tahun 2017.

Pada tabel 3., merupakan luas permukiman penduduk yang didapatkan melalui pengolahan data citra landsat dan dilakukan penghitungan pada luas permukiman yang ada pada tahun 2000, maka berdasarkan data yang didapatkan pada tahun 2000 luas permukiman penduduk yang paling luas permukimannya adalah Desa/ Kelurahan Penarukan, Anturan, Kalibukbuk, Kaliuntu, Banjar Tegal, sedangkan Desa/ Kelurahan yang luas permukimannya paling sedikit di Kecamatan Buleleng adalah Desa/ Kelurahan Banjara Bali, Kampong Singaraja, dan Kampong kanjana. 
Arah pertumbuhan permukiman penduduk pada tahun 2016 mengarah ke timur dan barat Kecamatan Buleleng. Desa/ Kelurahan yang merupakan wilayah pinggiran kota yang mengalami perluasan adalah Desa/ Kelurahan penarukan, banyuasri, dan Beratan, sedangkan wilayah desa yang mengalami perluasan permukiman penduduk adalah Desa/ Kelurahan Pemaron, Jinengdalam, Anturan dan Kalibukbuk.. Arah pertumbuhan permukiman yang terjadi di Kecamatan Buleleng pada tahun 2016 mengarah ke arah timur dan barat Kecamatan Buleleng, dapat dilihat pada peta arah pertumbuhan permukiman Kecamatan Buleleng tahun 2000 dan 2016 di bawah ini.

\subsection{Karakteristik Pertumbuhan Permukiman Di Kecamatan Buleleng}

Karakteristik pertumbuhan permukiman yang terjadi pada masing- masing Desa/ Kelurahan Di Kecamatan Buleleng dapat dilihat pada tabel 4., Luas pertumbuhan permukiman umum di Kecamatan Buleleng tahun 2016 dibawah ini:

Tabel 4. Luas Pertumbuhan Permukiman Tahun 2016

\begin{tabular}{|c|c|c|c|}
\hline \multirow[t]{2}{*}{ No. } & \multirow[t]{2}{*}{ Nama Desa/ Kelurahan } & \multicolumn{2}{|c|}{$\begin{array}{c}\text { Luas Pertumbuhan Permukiman } 2016 \\
(\%)\end{array}$} \\
\hline & & Pribadi & Umum \\
\hline 1. & Banyuning & 4,83 & 0,18 \\
\hline 2. & Tukadmungga & 0,78 & 0,13 \\
\hline 3. & Kalibukbuk & 2,5 & 0,22 \\
\hline 4. & Penarukan & 1,95 & 0,03 \\
\hline 5. & Baktiseraga & 2,74 & 0,06 \\
\hline 6. & Banyuasri & 5,11 & 0,01 \\
\hline 7. & Paket Agung & 0,37 & 0,17 \\
\hline 8. & Liligundi & 0,5 & 0,11 \\
\hline 9. & Anturan & 1,86 & 0 \\
\hline 10. & Pemaron & 0,99 & 0 \\
\hline 11. & Banjar Tegal & 4,22 & 0 \\
\hline 12. & Beratan & 5,01 & 0 \\
\hline 13. & Kampong Singaraja & 0,42 & 0 \\
\hline 14. & Kendara & 0,58 & 0 \\
\hline 15. & Astina & 3,47 & 0 \\
\hline 16. & Banjar Jawa & 3,27 & 0 \\
\hline 17. & Banjar Bali & 3,21 & 0 \\
\hline 18. & Kampong Kanjanan & 3,21 & 0 \\
\hline 19. & Kaliuntu & 3,78 & 0 \\
\hline 20. & Kampong Anyar & 3,23 & 0 \\
\hline 21. & Kampong Bugis & 3,21 & 0 \\
\hline 22. & Kampong Baru & 3,27 & 0 \\
\hline 23. & Jinengdalem & 0,92 & 0 \\
\hline 24. & Penglatan & 0,55 & 0 \\
\hline 25. & Petandakan & 0,91 & 0 \\
\hline 26. & Sari Mekar & 0,90 & 0 \\
\hline 27. & Nagasepaha & 0,54 & 0 \\
\hline 28. & Poh Bergong & 0,98 & 0 \\
\hline 29. & Alas Angker & 0,62 & 0 \\
\hline & Jumlah total & 63,93 & 0,91 \\
\hline
\end{tabular}

Sumber: Dinas Penanaman Modal Dan Pelayanan Perizinan Terpadu Satu Pintu Kabupaten Buleleng Tahun 2016. 
Berdasarkan Tabel 3.2, karakteristik permukiman di Kecamatan Buleleng yang terjadi di setiap Desa/ Kelurahanya berbeda-beda. Pada Tabel 4.11 data yang di peroleh dari dinas penanaman modal dan pelayanan perizinan terpadu satu pintu Kabupaten Buleleng tahun 2016, dari 29 Desa/ Kelurahan di Kecamatan Buleleng tahun 2016 terdapat 8 Desa/ Kelurahan yang mengalami pertumbuhan permukiman umum, diantaranya, Desa/ Kelurahan Banyuning permukiman pribadi 4,83 \% dan umum 0,18\%, Desa/ Kelurahan Tukadmungga pribadi 0,78\% dan umum 0,13\%, Desa/ Kelurahan Kalibukbuk pribadi 2,5 dan umum 0,22\%, Desa/ Kelurahan Penarukan pribadi 1,95 \%dan umum 0,03\%, Desa/ Kelurahan baktiseraga pribadi 2,47\% dan umum 0,06\%, Desa/ Kelurahan Banyuasri pribadi 5,11\% dan umu 0,01\%, Desa/ Kelurahan Paket Agung pribadi 0,37\% dan umum 0,17\%, dan Desa/ Kelurahan Liligundi pribadi $0,5 \%$ dan umum $0,11 \%$.

Desa/ Kelurahan yang paling banyak mengalami pertumbuhan permukiman umum adalah Desa/ Kelurahan Kalibukbuk dan paling sedikit Desa/ Kelurahan Banyuasri, sedangkan Desa/ Kelurahan yang karakteristik pertumbuhan permukiman pribadi paling banyak mengalami pertumbuhan adalah di Desa/ Kelurahan Banyuasri dan Banyuning dan paling sedikit Desa/ Kelurahan Kampong Singaraja dan Paket Agung. Maka karakteristik pertumbuhan permukiman yang terjadi di Kecamatan Buleleng menurut data yang diperoleh adalah didominasi oleh permukiman pribadi. 


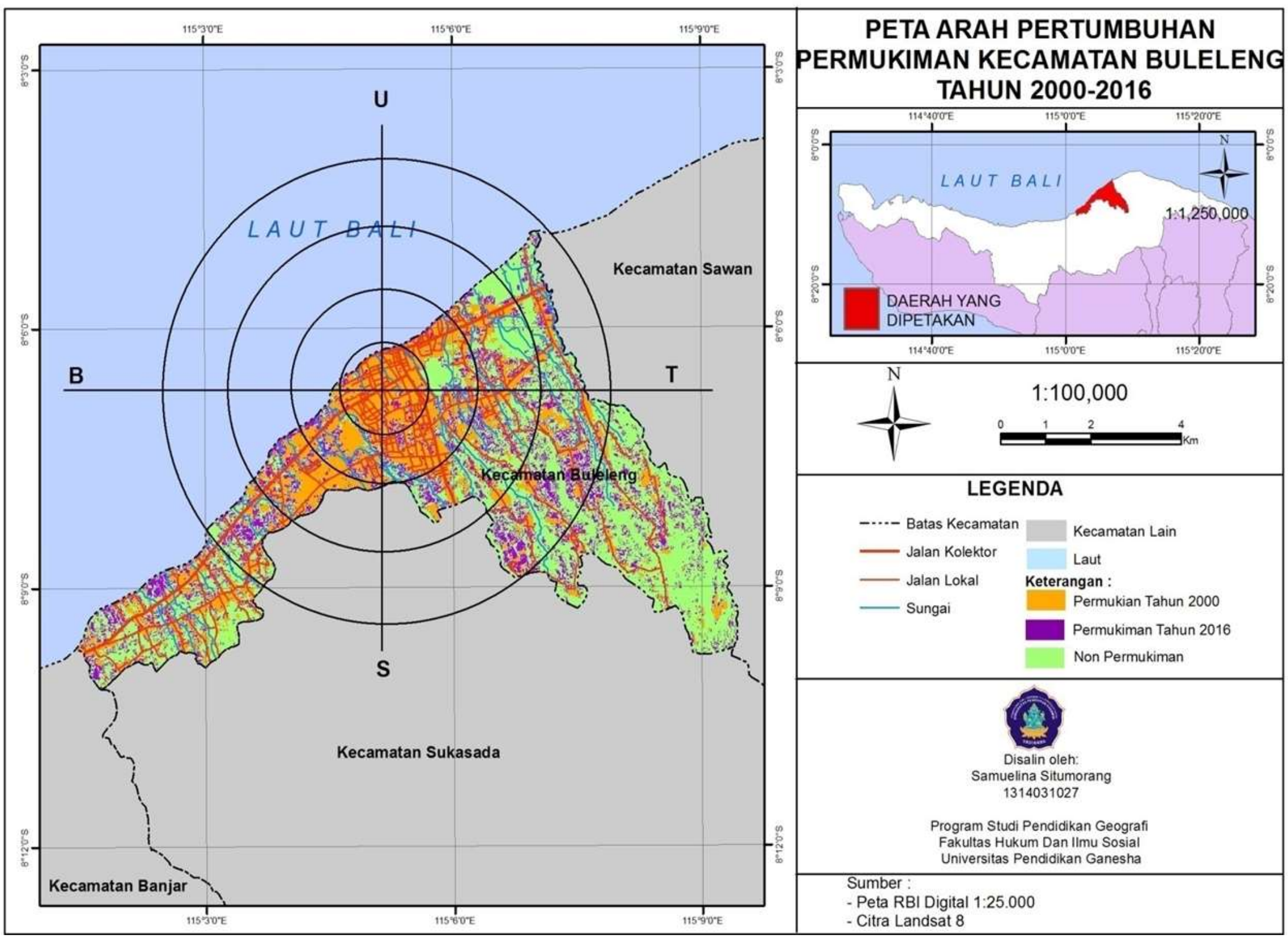

Samuelina Situmorang. / Pertumbuhan Permukiman di Kecamatan Buleleng 


\section{Simpulan dan Saran}

Tahun 2000 sampai 2016 pertumbuhan permukiman di Kecamatan Buleleng mengalami peningkatan sebesar 42, 74\%.Arah pertumbuhan permukiman penduduk di Kecamatan Buleleng mengarah ke arah timur dan barat Kecamatan Buleleng.Desa/ Kelurahan yang paling banyak pertumbuhan permukiman umum adalah Kalibukbuk paling sedikit Desa/ Kelurahan Banyuasri, sedangkan pertumbuhan permukiman pribadi paling banyak di Desa/ Kelurahan Banyuasri dan Banyuning paling sedikit di Desa/ Kelurahan Kampong Singaraja dan Paket Agung.Bagi masyarakat sebaiknya meningkatkan pengetahuan tentang beberapa hal yang berkaitan tentang pertumbuhan permukiman. Agar masyarakat mengetahui tentang dampak dari pertumbuhan permukiman dan yang mempengaruhi pertumbuhan permukiman penduduk.

Bagi pemerintah seharusnya lebih mampu menata ruang terbuka hijau yang ada, agar tidak terjadi alih fungsi lahan di beberapa daerah dan menyebabkan kepadatan permukiman penduduk yang kemudian dapat mengakibatkan kekumuhan terutama di daerah kota.

\section{Daftar Rujukan}

Badan Pusat Statistik Kabupaten Buleleng. (2010). Bali dalam angka 2010.

Badan Pusat Statistik Provinsi Bali. (2010). Bali dalam angka 2010.

Hariyanto. (2007). Strategi Penanganan Kawasan Kumuh Sebagai Upaya Menciptakan Lingkungan Perumahan Dan Permukiman Yang Sehat Contoh Kasus Kota Pangkalpinang. Jurnal Perencanaan Wilayah Dan Kota, 7(2), 11-37.

Ismail, R. M. M. A., Sriartha, I. P., \& Sutarjo. (2016). Kajian Permukiman Kumuh di Kota Singaraja. Jurnal Jurusan Pendidikan Geografi, 4(3).

Jati, V. I. M., \& Christanto, J. (2012). Kajian perkembangan permukiman wilayah peri urban di sebagian wilayah kabupaten sukoharjo tahun 2001-2007. Jurnal Bumi Indonesia, 1(1), 1-8.

Masitoh. (2003). Pengaruh Keberadaan Perumahan Terhadap Perubahan Harga Lahan Di Kecamatan Ciledug.

Masykur. (2006). Karakteristik permukiman dualistik dan tingkat keberhasilan penghuni studi kasus Kota Bogor Jawa Barat.

Susilo, S. (2015). Fertilitas Masyarakat Nelayan Di Desa Banjarkemuning Kabupaten Sidoarjo. Jurnal Pendidikan Geografi, 20(2), 46-52.

Undang Undang Dasar 1945 Pasal 28 Tentang Rumah.

Weran, B. A. (2017). Pengaruh Pertumbuhan Ekonomi dan Pertumbuhan Penduduk Terhadap Tingkat Kemiskinan Kabupaten Flores Timur. Jurnal Riset Edisi XIV, 3(3), 11-23.

Wesnawa, I. G. A. (2015). Geografi Permukiman. Yogyakarta: Graha Ilmu. 